\title{
Education Model "Bandongan" for Farmers Society of Agricultural Skills Training in the Background of Sosioculture "Pesantren" in East Java*
}

\author{
Ach. Fatchan \\ Faculty of Social Science, State University of Malang \\ ach.fatchan.fis@um.ac.id \\ Ach. Amirudin \\ Faculty of Social Science, State University of Malang \\ ach.amirudin.fis@um.ac.id \\ Hadi Soekamto \\ Faculty of Social Science, State University of Malang. \\ hadi.soekamto.fis@um.ac.id
}

Doi:10.5901/mjss.2015.v6n5p515

\section{Abstract}

\begin{abstract}
This study aims to describe and understand the implementation of skills training Model "Bandongan" for the peasant society in the background of sociocultural "pesantren" in East Java. "Bandongan" is a pattern of skills training with a group approach typical "pesantren" which resulted in humans as a whole. "Pesantren" is "Islamic boarding school". Thus, social change in rural farming communities sociocultural background "pesantren" always nuanced relegius. The study used qualitative research methods with a knife phenomenological analysis, to understand the actions of individuals based "because motives" and "in order to motives". The results showed that the actions of individual actors indigeniuos education model "bandongan" in a social change in the village-based "pesantren" is different. Meaning the actions of coaches influenced by the understanding of the Holy Quran, Al-Hadith, and the "yellow book", idol, the character of institutions, and traditions. Meaning action peasant society based on: (1) religious social rationality of the economic rationality, (2) the rationality of faith and piety to God almighty one, (3) the rationality of justice for society and religious life. The findings are in contrast to the thesis Geertz. Geertz view ignores the existence of the influence of the holy book, idol, character and local tradition. In these research findings, it has proven to give "orders" against one's actions.
\end{abstract}

Keywords: training model "bandongan", farming skills, and peasant society

\section{Introduction}

Learning system "bandongan" which is used for agricultural skills training is new model of education, at least for the education of agricultural skills. Education such skills until now prevails in rural East Java. Especially in villages which "pesantren". East Java community call the village "source of religion". Village "source of religion" is a growing village stands and based on sociocultural "pesantren". The village Such learning model "bandongan" is commonly practiced or has become a tradition. As noted by Dhofier (1983: 28) that the interaction system "bandongan" used to assess various religious sciences, such as the interpretation of the Koran, the Hadith, and examines various kinds of "Yellow Book" in the "pesantren" Java.

Steenbrink noted that "kiai" in Java always uses teaching system of "bandongan" when transfer of religious knowledge. "Kiai" is the leader of "Islamic boarding school". As we know that the teaching system of "Bandongan" has the distinctive advantages that can outcome skilled individuals and act honestly on the basis of ethical norms of Islam (Steenbrink, 1986: 227). In other words, the training system "bandongan" outcome human resources can be "intact". That is, to produce skilled man, science and technology, faithful and devoted, and can integrate with the knowledge of religious sciences. That sort of thing is a dream "pesantren" in East Java (Fatchan and Susilo: 2014: 17).

Such beliefs led to village-based agricultural training schools rejected an offer from the Department of Agriculture. The incident occurred in the village of Madusari-Malang in East Java in the era of the New Order and the Order of the 
Reformation. The rejection of the Integrated Agriculture Development training in Batu in East Java was caused: (1) The project was organized in collaboration with the World Bank. According to the understanding of managers "pesantren" bank financial services law "makruh". That is, if the work was done man does not get a reward from God; (2) The project is a pilot project of integrated farming patterns among commodities. Shaped like multiple cropping models and models of mixefarming. Such a model farm has been carried out by "pesantren" in Madusari (Fatchan, Soekamto, Mustafa: 2015).

According to the "kiai" in the village Madusari that agricultural training offered by the Department of Agriculture was mediocre. That is, the pattern of such farms has trained at his "pesantren". As indicated action one of "ustadz" named Maksum, who was trained 5 students in the fields. "Ustadz" is the teacher in "pesantren". Where rice was planted with chili, garlic, and onion in multiple cropping. Knowledge and skills acquired when learning technology infallible model of mixed crop cultivation to farmers advanced in Batu. Training that he did use model "bandongan". Where 5 people in a group of students "learning by doing" in paddy fields managed by infallible. Five of these students for 4 months doing "immershing" in everyday life "ustadz" infallible, ranging from going to the field to go to the mosque. Appeared that the system interaction "bandongan" done "outdoor study" for the learners in groups. Learning "outdoor study" can produce learning gains that are longterm memory (Fatchan, Amirudin, and Utaya: 2012: 21). Skills possessed by "kiai" and "ustadz" is distributed to farmers in the Islamic boarding school environment through model "bandongan". Such cases encountered in practice learning "Darug Classroom" conducted outside the classroom for Aboriginal communities in Australia (Harrison and Murray: 2012).

Various types of agricultural skills training model "bandongan" which has been performed in Islamic boarding school Mubtadliin, Malang, East Java include: multiple cropping, rice crops, melon plants, crops, vegetables, chickens, goats, and cattle. Implementation of skills training is done informally and not using the formal curriculum. This means that the implementation of training refers to the variety of life experiences "kiai" and the "ustadz" and the "senior students" as has been done by his predecessor.

Learning or training model "bandongan" used to train farmers around the "pesantren" is new to the world of education. Such training is common in the village of Java-based Islamic religion. In which there stands a Islamic boarding school. Interaction model "bandongan" it has become a tradition or custom in "pesantren" (Dhofier, 1983: 28). The model has the advantage can result in individuals who are skilled, honest act on the basis of ethical norms of Islam, and a man who is faithful and devoted (Steenbrink, 1986: 227).

\section{Research Methods}

This study used a qualitative approach that seeks to understand the significance of agricultural skills training model of "bandongan". The basic understanding upon in order to motives and because motives as suggested by Alfred Schutz (1972). The location of this research in the village Madusari-Malang East Java, village shows a complex phenomenon in line with the wishes and goals of this study. In the village has long exist a "pesantren" as a symbol of community identity, a source of religious ethics, and agricultural development for local communities. Collecting data using observation and participation in-depth interview to "kiai", "santri", and farmers who are directly involved in agricultural skills training. "Santri" is students in Islamic boarding school. Analysis of data using an interactive model as recommended by Miles and Haberman (1994: 10).

\section{Research Result}

\section{1 "Bandongan" as a model for training}

"Bandongan" comes from the Javanese word "bandong" that gets the suffix "an". "Bandong" means a group or cluster. "Bandongan" means grouped in bundles. Other terms of the "bandongan" is "weton" which means one output or one generation. "Bandongan" is an interaction with a group approach. Interaction takes place very familiar though not quite intimate. In the implementation of the training indicated that each group of "santri" to obtain the carrying out of different of a facilitator. Facilitator training is "kiai" and "ustadz" was the appropriate force. Training model "bandongan" applied to the "santri" senior, instead of "santri" novice.

\subsection{Philosophical Basis}

The cornerstone of the philosophy underlying the applied training model "bandongan" in Islamic boarding schools research subjects, namely: (1) Learning is an effort to gather as much knowledge; (2) Silent conditions are conducive 
atmosphere; (3) The words offend or authority "kiai" will be able to inhibit the blessing or knowledge that is not useful. That sort of thing, as also noted by the findings Dhofier (1983: 28) and Irhamni (1993: 92).

In everyday practice training model "bandongan" is a skills training where learners seek to accumulate knowledge and skills as much as possible. Interaction patterns tend to be one-way, in which the more active facilitator or coach in the learning process. However, when knowledge has been accumulated, then the students had a discussion and critical dialogue with fellow classmates. When they encounter problems, then the problem dialogue to the coaches. In practice, during the discussions and dialogue are normally found new things about the understanding of religious life and understanding of knowledge and skills that are being studied. Such "bandongan" model training is a type of training in Islamic boarding schools research sites.

\subsection{Purpose Model "Bandongan" for Skills Training}

The "pesantren" in the village Madusari interaction system "bandongan" is usually applied to learning "yellow book". Learning group with the ability and willingness of "santri". It is expected to spur the spirit of the "santri" in strengthening the relationship between actors and imitate exemplary interaction "kiai". In everyday life "santri" do "immersing" in the life of the fasilitator or teacher and the type of skills learned. Learners studying and learning by: (1) together in groups of contemporaries and skills learned, (2) a dialogue with trainers, (3) learning by doing in the field, (4) immershing in the religious life with the manager, (5) continuously familiarize and hone the skills learned.

On skills training model of "bandongan" is obvious that the implementation of the training leads directly to the specifications of the skills assessed. Thus, the totality of knowledge and skills of students in learning always involves an entry behavior, knowledge and skills that are being studied, and the conditions of the context of religious and social life of today (Knowles, 1986). Thus, the training model of "bandongan" this leads to a comprehensive understanding of religious knowledge. Furthermore, internalized as part of the wealth of knowledge and skills possessed, then practiced in everyday life in society (Steenbrink, 1986: 231; Irhamni, 1993: 102).

\subsection{Material and Training Evaluation}

As known, classically interaction system of "bandongan" is used to study a variety of "yellow book" that contains religious sciences from the point of view of the various existing science in "pesantren". Learning is done in groups according to the desired material each group. One group usually amounts to 5 to 20 and even up to 500 people (Dhofier, 1983: 28). Five people if it is to train "students insiders" and "students surrogate", 20 people if the cottage to train the students in general, and 500 people if it's a general instruction for students and the surrounding community. In the daily practice of teaching "bandongan" with a large number of learners, such as: (1) a general study conducted every Friday morning, (2) jama'ah tahlil, (3) istighosha, and the like.

Bandongan system was originally intended to study various "yellow book" in the form of rhythm (nadzm) and perform description problems (essei). Understanding of the material leads to a comprehensive study from the viewpoint of various knowledge and experience of life by collecting as much science. Evaluation and monitoring of the implementation of the training is done at the time learners undertake discussions and dialogue with the "ustadz". Around the ability to translate the book in terms of textual and contextual meaning is the most urgent reference in determining the ability of the learner assessment. Knowledge and skills have been mastered if students have demonstrated the following capabilities: (1) speak in public, (2) guiding a study, (3) to guide group discussions, (4) capable of leading and managing a particular activity. For example: students has been able to lead and manage the activities of the agricultural skills training.

\subsection{Pattern Training System of "Bandongan"}

In the interaction system of "bandongan" learners can meet face to face in groups, dialogue among participants, and sometimes direct dialogue with "kiai" or "ustadz". Kiai is a resource that transfer knowledge and skills and to be imitated in the form of dye in everyday life. Therefore, the fasilitator on the interaction of the system "bandongan" are those options are not only good at science and religion, but also devoted to God. As reflected in the tradition in "pesantren", each will begin an activity always read "bismillah" and or "Al-Fatihah" and the end of activity always read the "Alhamdulillah".

Implementation of the system interaction "bandongan" in studying the "yellow book" as a study material in "pesantren" in village Madusari indicate the following: (1) The teacher read and decipher carefully trained to the material; (2) Teacher provide an explanation by providing comments on the meaning that nothing in the text; (4) Teacher to review 
what is studied and relate it to the current contextual conditions; (5) Learners in groups to listen and analyze by giving various signs or notes in the material covered or leave a note "jenggotan" or "beard".

In interaction of "bandongan" sorting group of learners as follows: (1) joined in one interest group, (2) incorporated in a skill to be developed, (3) incorporated in a basic capability possessed. Such separation makes the learners can learn and practice freely with pleasure and not because of pressure. With so learning is a process of development of knowledge and skills with pleasure not because of pressure or fear (Pine and Horn, 1987). Implications for the development of the individual is that he becomes individual learning fun and in line with the interests and talents.

\subsection{Implementation Model of "Badongan" for Agricultural Skills Training}

System interaction of "bandongan" for an agricultural skill training in rural Madusari show the following: (1) Training addressed to a group of "santri ngawulo" and farmers who become "santri kalong" who want agricultural practice skills; (2) Teacher according to the skills possessed train a group of learners are learning by doing in the rice paddies and fields; (3) Students do internships working within a certain time; (4) "Santri" follow and "immershing" in farming activities carried out by the trainer; (5) At certain times in group discussions among coaches with learners; (6) Discussion and dialogue are usually carried out in the dormitory room, at work, at home to cattle, in rice paddies and fields, or other place of work practices. Evaluation of training is done on going, implicitly, and continuously during work practices.

End of the training or the training success is characterized by indicators learners are able to do the job skills properly. At that moment the coach decides that learners are given the opportunity to work independently. It implies that there is a willingness to pass on agricultural skills possessed coaches to students who practice skills as owned by the trainer. In such a way that the skills possessed by the "pesantren" always inherited. In other words, "santri senior" who have certain skills --after farming them out of the "pesantren"-- first passing skills possessed the "santri junior".

Example: the implementation of the agricultural skills training to plant "melon" with model of "badongan" in "pesantren Mubtadliin" in the village Madusari. Patterns of guidance, training, and development performance of learners who were practicing planting "melon", as shown in Table 1.

Table 1: Performance During Practice Maintaining Melon Plants In Training Model of "Bandongan"

\begin{tabular}{|c|c|c|}
\hline Work activity in Every 2 Weeks & Implementation of Activities Mentoring of Cultivating the Land to harvest & Skills Mastery (\%) \\
\hline 1 & Always guided & 10 \\
\hline 2 & Sometimes guided & 40 \\
\hline 3 & Occasional guided & 65 \\
\hline 4 & Start standalone & 80 \\
\hline 5 & Already standalone & More than 85 \\
\hline
\end{tabular}

The observation of the performance of the practice of planting "melon" shows as follows: (1) during the first 2 weeks, the working practices of students still want always to be guided; (2) In the second week to two, students have started to master the skills and only occasionally needs to be nurtured; (3) In the two weeks to three, coaching is done only occasionally; (4) In the second week four, the performance of the learners have been able to practice alone. In other words, students have been able to master the melon maintain employment by $80 \%$ or more; (5) In the two weeks to five, students have been able to control more than $85 \%$ skill maintain plants "melon".

Research findings related to the meaning contained in the rejection of the existence of the bank, so that the "students" do not want to be trained by the World Bank program in City of Batu. However, "pesantren" do their own farming skills training model "bandongan". According to the understanding of managers "pesantren" in village of Madusari East Java that the existence of legal bank "makruh". The full meaning of these actions can be seen in Table 2.

Table 2: Reject the Existence of the Bank and Implement Training Model "Bandongan"

\begin{tabular}{|c|c|c|c|}
\hline \multirow{2}{*}{$\begin{array}{l}\text { Banks in understanding the } \\
\text { existence of "Pesantren" }\end{array}$} & \multicolumn{3}{|c|}{ Understanding of The Meaning of Actions Subject } \\
\hline & Action of Kiai & Action of Santri & Action of Famers \\
\hline $\begin{array}{l}\text { Deny the existence of the Bank, } \\
\text { but apply } \\
\text { Model of Bandongan for } \\
\text { agricultural skills training }\end{array}$ & $\begin{array}{l}\text { 1) Pattern of thinking: } \\
\text { religious institutions, } \\
\text { pesantren, kiai earlier. } \\
\text { 2) Because motives: } \\
\text { Law "makruh" in Islam, many } \\
\text { farmers refused credit, the }\end{array}$ & $\begin{array}{l}\text { 1) Pattern of thinking: } \\
\text { kiai leadership of boarding schools, } \\
\text { religious institutions, kiai earlier. } \\
\text { 2) Because motives: } \\
\text { Law "makruh" in Islam, many farmers } \\
\text { refused credit, the potential model }\end{array}$ & $\begin{array}{l}\text { 1) Pattern of thinking: } \\
\text { kiai, village religious institutions. } \\
\text { 2) Because motives: } \\
\text { Law "makruh" in Islam, Bank loan } \\
\text { irregularities that have occurred, the } \\
\text { potential model "bandongan" for }\end{array}$ \\
\hline
\end{tabular}




\begin{tabular}{|c|c|c|c|}
\hline & $\begin{array}{l}\text { potential model "bandongan" } \\
\text { for agricultural skills training. } \\
\text { 3) In order to motives: } \\
\text { In order to strengthen the self- } \\
\text { existence, can reward from } \\
\text { Allah, can strengthen the } \\
\text { training model "bandongan". }\end{array}$ & $\begin{array}{l}\text { "bandongan" for agricultural skills training. } \\
\text { 3) In order to motives: } \\
\text { In order to strengthen the existence of } \\
\text { himself as a big family Kiai, can reward } \\
\text { from Allah, can strengthen the training } \\
\text { model "bandongan" }\end{array}$ & $\begin{array}{l}\text { agricultural skills training. } \\
\text { 3) In order to motives: } \\
\text { In order to get a reward from God, can } \\
\text { avoid disaster, the training model } \\
\text { "bandongan" can be done continuously. }\end{array}$ \\
\hline Themes found Measures & Actions "Lecet" or Blisters & Actions "Lecet" or Blisters & \begin{tabular}{|l} 
Actions "Lecet" or Blisters \\
\end{tabular} \\
\hline
\end{tabular}

Kiai, santri, and farmers in rural study sites act rejection of the existence of the bank. However, they develop a pattern of "bandongan" for agricultural skills training and capital to develop farming through the institution of "jamiliyah". The action called the "lecet" or "Blisters" a solution containing many meanings. Meaning that the main thing is their motive continuity and existence model of "bandongan" for agricultural skills training. The training according to the understanding of "pesantren" are able to produce quality human resources as a whole. In a sense knowledgeable and highly skilled who are always faithful and devoted to God. Based on the variety of the above description can be built a new proposition which found if this research is as follows.

\subsection{Proposition}

When the potential of the skills possessed "pesantren" causes the training model of "bandongan" applied for the training. Such action is called an act of "blisters". The objective of "blisters" in order to maintain the existence of public figures, close to a variety of social strata, and can support farmers in the surrounding community.

Social change in rural farming communities based schools affected by the local education transformation model, understanding of religious norms, and the existence of religious institutions concerned.

Based on the research findings related to the implementation of the training model of "Bandongan" for agricultural skills that have been carried out in "pesantren" Mubtadliin in Madusari Malang, East Java. This research found Bandongan Model for Training of Agricultural Skills, named BMT-AS models as can be seen in Figure 1. Model of BMTAS perfect for model "The Systematic Design of Instruction" introduced by Dick and Carey (1990). Improvements can be improved lies in the techniques of learning evaluation, remedial patterns, and the learning outcomes that are intact. Evaluation models of BMT-AS is done simultaneously and on going which is not shown in the model of Dick and Carey. Full results of the study implies that the outcome of the learning which students skillful and godly in the run and devout religion in social life.

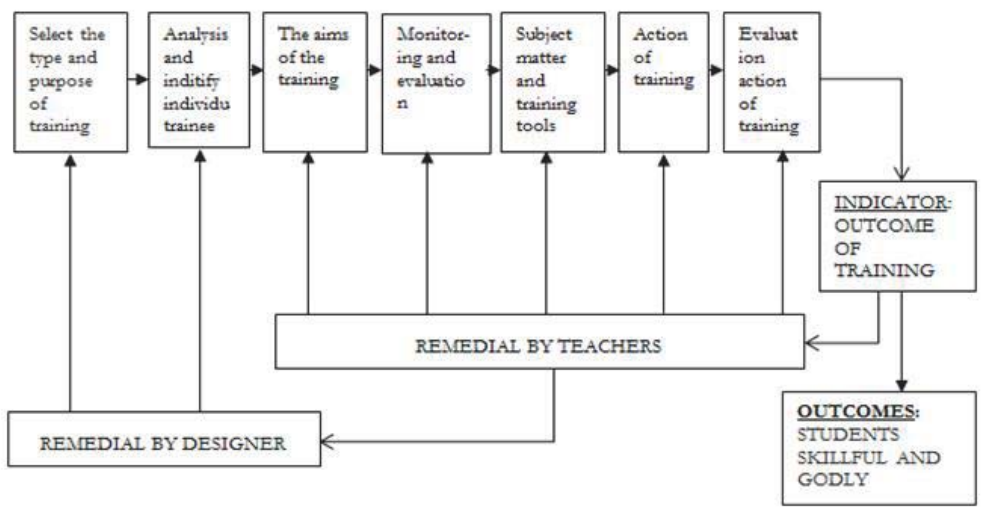

Figure 1: Model of BMT-AS (Bandongan Model for Training of Agriculture Skills)

\subsection{Remark}

1) Select the type and purpose of training adapted to the conditions of sociocultural context "pesantren".

2) Analyze and identify individual training learners in line with the ability and willingness of skills desired by learners. 
3) Formulate training purposes in the form of training activities formulate specific goals in line with the desired skills learners.

4) Determine the monitoring and evaluation will be carried out, related to: when, how, what indicators are used, and what solutions are needed to make the implementation of the training runs as desired.

5) Determine the materials and training tools, associated with training and equipment to determine the characteristics of what is needed in the training.

6) The pattern of the training model BMT-AS, the training is done in groups with work while practicing the technique learning by doing and immershing with the fasilitator while training takes place.

7) Pattern evaluation conducted continuous training for implementation by observation of behavior and dialogue with fellow students and teachers and the achievement of training success indicator.

8) Remedial, an effort to improve the implementation of each component of the training and implementation of training programs. Implementation of remedial performed continuously on each indicator achievement of the training

\section{Discussion}

The research findings showed that the model of "Bandongan" skills training has become a trade mark "pesantren". The model not only for learning "yellow book", but also applied to train agricultural skills. This model is a product of indigeneous "pesantren" which has long been entrenched. Excellence training model that is able outcome quality human resources, skilled, responsible, moral, and devoted. Meaning that the knowledge and skills acquired learner is on loan from Allah that must be carried out to others as a way of worship. This is a result of the process of "immershing" during the training. Such learning pattern is a pattern of human learning. By Knowles (1986) referred to as "learning how to learn". Instead of teaching the nuances of training patterns that lead to "the art and science of teaching children" as noted by Gagne and Berliner (1977).

BMT-AS training pattern oriented that learning is not a pressure, but it is a process of awareness is done with pleasure, as recorded by Pine and Horn (1987). If viewed from the side of the communication patterns are applied, then the training pattern BMT-US models use a two way interaction patterns of communication traffic (Rogers, 1983).Thus, it can generate induvidu attitudes and actions based on the consciousness and high moral responsibility, as described by Maftuh (1997). In the training appeared that the moral religion is a major consideration.

Pattern of thinking orientation of the coach or teacher acts implementing the model BMT-AS training in farming activities, namely: (1) the condition of the institution "pesantren" which from the beginning has been accustomed to farming, (2) "kiai" as the head of Islamic boarding school who liked farming. "In order to motives" apply the model of BMTAS for agricultural skills training, namely: (1) in order to training continuously to the "santri" and farmers around the "pesantren", (2) in order to create individuals who behave more religious, (3) in order to increase production and income in agriculture. "Because motives" for applying BMT-AS models for agricultural skills training, namely: (1) agricultural activities have become a tradition in "pesantren", (2) a lot of people are smart and skilled but low devotion to god and easy to corruption, (3) training conducted Department of Agriculture only economic oriented, but ignore the religious moral.

The most troubling conditions for "pesantren", why "pesantren" apply BMT-AS training model for the skills of farming is their religious moral degradation that hit farmers around the "pesantren". It was shown for the behavior of individuals around the "pesantren" which is further away from religious piety. They tend to behave economic oriented. They tend to behave not balanced between the science and technology are controlled by faith and "taqwa" owned (Zahar and Marshal, 2001: 3-4; Toprak, 1999: 16). The fact that the "pesantren" have the potential and ability to improve the behavior through training BMT-AS models. Furthermore, the manager of "pondok pesantren" has been used to farm with a variety of farm commodities.

Steenbrink noted that the human resource development of Islamic institutions there has never been any material which provides the Islamic religion and general science into one package as a whole, except for "pesantren" (Steenbrink, 1986: 231). What Steenbrink note found in "pesantren" Mubtadliin-Malang, East Java. The "pesantren" is long since been implementing educational pattern formulate religious knowledge, science non-religious, and skills become practical in everyday actions through model "bandongan". As known western education system on behalf of democracy and secular educational system to make it not to grow and become militant, as the phenomenon of "Boko Haram" in Negeria (Ugwuona, 2015: 54). Operationalization of religious life in the form of tangible actions such everyday makes boarding is one of the institutions that must be taken into account for the development of qualified human resources in rural areas. It is a must for Islam because in Islam view of religious life and community life are fused like sides of a coin (Steenbrink, 
1986: 223).

Robustness spirit of religious life and secular life in the spirit of Islam in Java is also found in the study Geertz (1974: 184). He noted there is a positive relationship between the ethics of Islam against the spirit of capitalism on society "pesantren" community. In a more universal religious studies, his thesis is actually in line with what has been proposed by Weber. He noted that the Protestant religious ethics correlated positively with the spirit of capitalism. Protestant religious someone who worked hard to develop and build wealth during his life in the world, just as he builds wealth for life in the hereafter (Weber, 1976: 85-87). By doing so, man during the life in the world is not supposed to be lazy, but they need to work more actively in pursuit of a better life, both for the life of the world and good for the life hereafter. Managing life and whole life is organized between the divine life, human life, and the life of nature in daily life is an ideal. That sort of thing in the view of the people of Bali sociocultural referred to as "Tri Hita Karana" (Surya, Thoyib, Fatchan, Rahayu: 2014: 16).

According to Geertz that one of the symbols of the life-hereafter harmonious world of someone among others presented in the form of religious rituals of everyday life. In rural Java in the community "peasant society" found that the pattern of action and life of farmers strongly associated with religious events, because it is the pattern and action guidelines for farmers (Geertz, 1998: 31-32). Geertz studies in 1970 describes in detail the relationship between religious rituals with a variety of agricultural activities, such as on the relationship with the harvest or planting ceremony. However, Geertz never mentioned what the underlying motives and causes of action, and never explained so that what they are doing such an act. The final thing is what distinguishes this research with the research findings Geertz.

Geertz recognizes that an understanding of the religious act of Java rural communities are still very open to corrections to the interpretation, more specifically to the "genuine goods". For the culturally each individual action is needed more accurate understanding according to the latest facts which may have not been revealed (Geertz, 1995: 7981). In it Geertz little attention to aspects of the existence of the holy book, idol, the character of the institution related to the religious life, as well as a proven tradition of community giving "orders" in the background of one's actions. As well as being found in Madusari, "kiai" in applying the pattern of agricultural skills training with a model of "bandongan" or BMTAS motivated by an understanding of the scriptures --Al-Qur'an, al-Hadith, and various "kitab kuning"-- studied, idol, the character of the institution, community traditions, as well as a variety of motives and reasons destination.

Action "santri" in East Java -in Madusari vallage-- refused trained by the Department of Agriculture is not a thesis of collective action such as "moral economy" Scott (1976). However, it is a rational act upon "in order to motives" and the motive causes do individually. It was different with the thesis of "political economy" Popkin (1979). Rejection of training from the Department of Agriculture and conducting training BMT-AS models, it strengthens the presence of Islamic boarding institutions. This is demonstrated by the fact that the pattern model of BMT-AS training for business skills of farmers is an attempt to marry the patterns of interaction that has long been dominated by the "esantren" of the application of new technologies in agriculture. The goal for human resources product future of technologically skilled and religious act. That means strengthening the economic outlook political arguments that explain that the movement made a "kiai" and anti-feudalism students can build new traditions. Where BMT-AS training model that is usually only used to assess the "yellow book" applicable to transfer of agricultural skills. Thus, action orientation of farmers not only on the conditions past and present but also the future (read: the motive causes and in order to motives) as noted by Susilo, and Fatchan (2014).

Based on various descriptions of the above, the findings of this study complement the moral economy thesis developed by Scott that tends to lead to a change oriented towards the past and the present. It was apparent when "Kiai" and students act training agricultural skills with BMT-AS models. Models such training is orientated towards the motive cause and a variety of situations and conditions. However, it is also oriented to the future on the perspective in order to motives of the faith and piety. It was shown that individual actions are not only a reality of action that maintains the traditional institution of "pesantren", but also develop on a rational basis.

Rationality was based understanding of social, cultural, religious and ethical norms. So that the training action is done for the sake of real justice, namely justice for themselves, society, and religious life. In developing the knowledge and skills of the "pesantren" do social engineering, adaptation, and even refused in accordance with the level of understanding of the ethical norms of religious, social, economic and cultural.

\section{Conclusion}

In an effort training farming communities, "pesantren" apply BMT-AS training model which is usually used to assess the "yellow book". The training model believed capable to product skilled individuals and act honestly on the basis of religious ethical norms. Individual action is an action that is based on the motive cause and in order to motives of each farmer actors of social change. The findings are in contrast to the thesis Geertz, where Geertz view ignores the existence of the 
influence of the holy book, idol, character and local tradition. The findings of this research indicate that the understanding of scripture, idol, character and local tradition proved to give "orders" against one's actions. The difference was shown in skills training BMT-AS models affected by the understanding of the holy book of the Qur'an, al-Hadith, and the "yellow book". Furthermore, it is also influenced by the idol, the character of the institution, and tradition. Meaning the action taken "peasant society" based on: (1) religious social rationality of the economic rationality, (2) the rationality of faith and piety to God almighty one, (3) rationality justice for themselves farmers, communities and religious life.

The findings of this study also supplemented the moral economy thesis Scott is likely to lead to a change oriented towards the past and the present. The research findings show society oriented towards social change: (1) the past in the form of motive causes and various situations and conditions background, (2) future in the form of perspectives in order to motives of the faith and piety. Thus, this study was shown that individual actions are not only a reality of action that maintains the traditional institution "pesantren", but also develop on the basis of rationality of "pesantren".

\section{Acknowledgement}

*The study was sponsored by the Indonesian Institute of Sciences

\section{References}

Dhofier, Zamarkhsyari, 1983, Pesantren Tradition Study of view "Pondok Pesantren". Dissertation at ANU Australia. Jakarta. Publisher LP3ES.

Dick, W. and Carey, Lau. 1990. The Systematic Design of Instruction. Third Edition. USA: Harper Collins Publishers.

Fatchan, Ach; Amirudin, Ach; Utaya, Sugeng. 2012. Effect of Learning Task Group Based on Field Survey (Outdoor Study) for Scientific Writing Ability and Student Results. Journal of Education No. 22 April 2012 ISSN 0854-8323 (pages 18-35).Malang. Research Institute of the State University of Malang.

Fatchan. Ach; Hadi Soekamto; and Mustafa. 2015. Defections "Kiai", "Ustadz" and Farmers In The New Order and The Reform Order In The Islamic Tradition In Rural East Java. Journal of Culture, Society and Development. Vol.5, No. 10 (2015). ISSN (Paper) 2224-5766 ISSN (online) 2422-8400. International Istitute for Science Technology and Education.

Gagne, NL and DC. Berliner, 1977, Educational Psycology. New York, USA. Gulf Publishing.

Geertz, Clifford, 1995, Culture and Religion, interpreter Budi Hardiman. Yogyakarta. Publisher Canisius.

Geertz, Clifford, 1998, relegion as a Cultural System, in Sociology of Culture Journal, file: II/ c / INTERNET / NETSCAPE / CUMIS, 10/28/96 / 09:40.

Geertz, Clifford, 1974, Religion As a Cultural System in The Interpretation of Cultures: Selected Essays. London. Basic Books Inc.

Harrison, Neil and Murray, Belinda. Refflective 2012. Teaching Practice in a Darug Classroom: How Teachers can Build Relationships with an Aboriginal Community Outside the School. Australia. The Australian Journal of Indigenous Education. Vol.41, Issue 02, December 2012. (pp139-145)

Irhamni, 1993, Interaction Patterns Arabic in Pesantren Tebuireng and Pond Rice, Vol.93 / / / 22/1993. Japan. The Toyota Foundation

Knowles, Malcolm, 1986, The Adult Learning: A Neglected Specie. Houston. Gulf Publishing.

Maftuh, Bunyamin, 1997, Development of Moral Considerations In Among the Pupils, Journal of Education Vol 7/1/April 19977. Bandung. Bandung Teachers' Training College.

Miles, Matthew B and A Michael Huberman, 1995, An Expanded Sourrcebook: Qualitative Data Analysis, London. Sage Publications.

Ugwuona, Crescentia Nwaeze. 2015. Boko Haram as a Topic in Nigerian Print Media from 2011-2012. Journal of Culture, Society and Development. Vol.5, 2015. ISSN 2422-8400. International Istitute for Science, Technology and Education (pp: 53-57)

Pine, Gerald J and J Peter Horn. 1987. Educational Policy: Adult caracteristic and Theory of Learning. Dowling Fall Quarter, The Ohio State University.

Popkin, Samuel L, 1979, The Rational Peasant: The Political Economy of Rural Society in Vietnam. Berkeley. University of California Press.

Rogers, Everett M, 1983, Diffusion of Innovations. New York. The Free-Press, A Division of Macmillan Publishing Co. Inc.

Scott, James C., 1976, The Moral Economy of the Peasant, New Haven, USA. Yale University Press.

Schutz, Alfred, 1972, The Phenomenology of the Social World. London. Heinemann.

Steenbrink, Karel. A, 1986, Pesantren Madrasah, School: Islamic Education in Modern Period. Dissertation series at the Catholic University of Nijmegen

Surya, Thoyib, Fatchan, and Rahayu. 2014. The Tri Hita Karana Culture Effect on Company Performance, Leadership, and Organizational Commitment (late Studies Regional Water Company in Bali Province. International Journal of Business and Management Invention. ISSN (online): 2319.8028 ISSN (Print) 2319.801X www.ijbi.org Volume 3 Issue 6 June / pp.31-22.

Susilo, Suko and Fatchan, Ach. 2014. The Comparation Social Change Community Farmers in the Village Islamic Boarding School Beckground. Journal of Geography and Education. Th 19 No. June 2, 2014. ISSN 0853-9251 (pages 15-32) Malang. Department of Geography-FIS State University of Malang

Toprak, Binnaz, 1999, Islam and Political Development in Turkey. Yogyakarta. Tiara Wacana-The Ford Foundation. 
Weber, Max, 1976, The Protestant Ethic and the Spirit of Capitalism. London. Allin and Bacon.

Zohar, Danah and lan Marshall, 2001, SQ Spiritual Intelligence Leveraging In Integralistic and Holistic Thinking To Understanding Life. Jakarta. Mizan Publishers 